January 9, 2007

\title{
What is happening to the impact of financial deepening on economic growth?
}

\author{
Peter L. Rousseau \\ Vanderbilt University \\ Department of Economics \\ Box 1819 Station B, Nashville, TN 37235, USA \\ and National Bureau of Economic Research \\ peter.L.rousseau@vanderbilt.edu.
}

\author{
Paul Wachtel \\ Stern School of Business \\ New York University \\ 44 West $4^{\text {th }}$ Street \\ New York, NY 10012 USA \\ pwachtel@stern.nyu.edu
}




\title{
What is happening to the impact of financial deepening on economic growth?
}

By Peter L. Rousseau and Paul Wachtel

\begin{abstract}
Although the finance-growth relationship is now firmly entrenched in the empirical literature, we show that it is not as strong in more recent data as it was in the original studies with data for the period from 1960 to 1989. We consider two related explanations. First, excessive financial deepening or too rapid growth of credit may have led to both inflation and weakened banking systems which in turn gave rise to growthinhibiting financial crises. Second, excessive financial deepening may be a result of widespread financial liberalizations in the late 1980s and early 1990s in countries that lacked the legal or regulatory infrastructure to exploit financial development successfully. We find that the increased incidence of financial crises since the 1990s is primarily responsible for the recent weakening of the finance-growth link, but find no direct evidence that liberalizations played an important supporting role.
\end{abstract}

Keywords: finance-growth nexus, rolling regression, robustness, cross-country growth JEL Codes: E44, G10, O40 


\section{Introduction}

Among the strongest elements of the modern economists' canon is that financial sector development has a significant impact on economic growth. A generation ago, economists like Goldsmith (1969) ${ }^{1}$ and McKinnon (1973) began to draw attention to the benefits of financial structure development and financial liberalization. In 1991 (p. 12) McKinnon could write with confidence that:

"Now, however, there is widespread agreement that flows of saving and investment should be voluntary and significantly decentralized in an open capital market at close to equilibrium interest rates.”

Since the 1990s, a burgeoning empirical literature has illustrated the importance of financial sector development for economic growth. Despite the growing consensus, however, we find that the link between finance and growth in cross-country panel data has weakened considerably over time. At the very time that financial sector liberalization spread around the world, the influence of financial sector development on economic growth has diminished.

The seminal empirical work that established the growth-finance link is King and Levine (1993), which extended the cross-country framework introduced in Barro (1991) by adding financial variables such as the ratios of liquid liabilities or claims on the private sector to gross domestic product (GDP) to the standard growth regression. They found a robust, positive, and statistically significant relationship between initial financial conditions and subsequent growth in real per capita incomes for a cross-section of about 80 countries. In the subsequent decade numerous empirical studies expanded upon this, using both cross-country and panel data sets for the post-1960 period. ${ }^{2}$

In this paper we reexamine the core cross-country panel result and find that the impact of financial deepening on growth is not as strong with more recent data as it appeared in the original panel studies with data for the period from 1960 to 1989 . We

\footnotetext{
${ }^{1}$ Goldsmith, for example, found a positive relationship between economic growth and financial development using a comparative approach with data for thirty-five countries over the period from 1860 to 1963.

${ }^{2}$ Levine (1997) surveys the literature through the mid-1990s, and Levine (2005) offers a comprehensive treatment of the many contributions that have followed. See also Temple (1999).
} 
consider two related explanations. First, we suggest that financial deepening has a positive effect on growth if not done to excess. Rapid and excessive deepening, as manifested in a credit boom, can be problematic even in the most developed markets because it can both weaken the banking system and bring inflationary pressures. We test this hypothesis by looking at the finance-growth nexus among countries that have or have not experienced financial sector crises. We find that once crisis episodes are removed, the finance-growth relationship remains intact. Its weakening over time thus seems to be a result of an increased incidence of crises in later years.

Second, we consider whether this type of unproductive financial deepening resulted from the widespread liberalization of financial markets that occurred in the late 1980s and early 1990s. This hypothesis is reminiscent of Robert Lucas's famous critique of econometric policy evaluation advanced three decades ago. In Lucas (1975) the focus was on the now-obvious misuse of the Phillips curve in formulating policy prescriptions, but the basic lesson may apply in our application as well. In particular, policies that have promoted and/or forced increases in financial depth over the past two decades, perhaps in response to the prevailing Washington consensus, may have altered the basic structural relationship between finance and growth. This could occur if the observed benefits of financial deepening led many countries to liberalize before the associated legal and regulatory institutions were sufficiently well developed. As a consequence, the impact of financial deepening on growth would become smaller. The two explanations are related in that premature financial development can lead to financial crises that have real effects. Our evidence suggests that if recent liberalizations are responsible for the breakdown of the finance-growth link, however, it is occurring through this indirect route, as we do not find a direct link from financial liberalizations to cross-country differences in the effect of financial deepening on growth.

Although the finance-growth nexus has become firmly entrenched, this is not the first study to question its importance. Economists as disparate as Joan Robinson and Robert Lucas have expressed doubts about the link. ${ }^{3}$ In addition, some authors have been less

${ }^{3}$ Lucas (1988) suggests that the role of finance is "over-stressed" and Robinson (1952, p. 80) asserts that "where enterprise leads, finance follows." 
than enthusiastic about the strength of the recently established empirical consensus and there are indications that the relationship varies and lacks robustness. ${ }^{4}$

A few earlier papers have noted that the relationship between financial deepening and growth varies considerably (e.g. Demetriades and Hussein (1996) and Arestis, Demetriades, and Luintel (2001)). Further, Rousseau and Wachtel (2002) show that the relationship varies with the inflation rate; financial deepening does not affect growth when the annual inflation rate is above a threshold between 13 and 25 percent. Rioja and Valev (2004) show that the relationship varies with the level of economic development. Specifically, deepening has a larger impact on growth with a moderate level of financial sector development. However, none of the earlier studies has provided an explanation for why the relationship has weakened over time.

A recent paper by Loayza and Ranciere (2006) addresses the dual role of financial deepening discussed above. They distinguish between the short run impact of credit expansions on growth and the long run positive of financial deepening on growth. The short run effect is sometimes negative particularly during episodes of financial crisis. Our approach to this dual role of finance is somewhat different. First, we will investigate how banking crises and liberalizations affect the impact of financial deepening on growth. Second, we will relate these phenomena to the secular decline in the impact of financial deepening observed in the classical cross country panel regression framework.

The next section describes the data and the by now standard approach to panel estimates of growth equations. In the following section we present baseline estimates and show that the finance growth nexus has weakened over time. In the next section we examine the hypotheses suggested above regarding financial crises and financial liberalizations. Section 5 presents some additional evidence on the relationship between the finance effect and the levels of economic development and financial depth in a country. Our conclusions are in Section 6.

4 The titles of some recent papers express the growing skepticism: e.g. "How much do we really know about growth and finance?” Wachtel (2003) and "Finance causes growth: Can we be so sure?” Manning (2003). 


\section{Data and methodology}

Our study includes cross sectional and panel data on financial and macroeconomic indicators for 84 countries over the period from 1960 to 2003. ${ }^{5}$ Data are from the 2005 edition of the World Bank's World Development Indicators database. The selection of countries is based on data availability from this source. To ensure comparability with King and Levine’s original study and others, we use three familiar measures of financial development, namely the ratios to GDP of liquid liabilities (M3), liquid liabilities less narrow money (M3 less M1), and credit allocated to the private sector. M3 as a percent of GDP has become a standard measure of financial depth and an indicator of the overall size of financial intermediary activity in cross-country studies. M3 less M1 removes the pure transactions asset and the credit measure isolates intermediation to the private sector from credit allocated to government or state enterprises. ${ }^{6}$

King and Levine's (1993) version of the Barro growth regression, and the starting point for our analysis, has the form

$$
\mathrm{Y}_{\mathrm{it}}=\alpha_{0}+\alpha \mathrm{F}_{\mathrm{it}}+\beta \mathrm{X}_{\mathrm{it}}+\mathrm{u}_{\mathrm{it}}
$$

5 The 84 countries are Algeria, Argentina, Australia, Austria, Bangladesh, Barbados, Belgium, Bolivia, Brazil, Cameroon, Canada, Central African Republic, Chile, Colombia, Costa Rica, Cote d’Ivoire, Denmark, Dominican Republic, Ecuador, Egypt, El Salvador, Fiji, Finland, France, Gambia, Ghana, Greece, Guatemala, Guyana, Haiti, Honduras, Iceland, India, Indonesia, Iran, Ireland, Israel, Italy, Jamaica, Japan, Jordan, Kenya, Republic of Korea, Lesotho, Luxembourg, Malawi, Malaysia, Malta, Mauritius, Mexico, Morocco, Nepal, Netherlands, New Zealand, Nicaragua, Niger, Nigeria, Norway, Pakistan, Panama, Papua New Guinea, Paraguay, Peru, Philippines, Portugal, Rwanda, Senegal, Sierra Leone, South Africa, Spain, Sri Lanka, Sudan, Sweden, Switzerland, Syrian Arab Republic, Thailand, Trinidad and Tobago, Togo, Turkey, United Kingdom, United States, Uruguay, Venezuela, and Zimbabwe.

6 A number of studies, including Levine and Zervos (1998) and Rousseau and Wachtel (2000), expand the set of financial indicators to include measures of stock market size, trading, and turnover. Most find a positive and statistically significant correlation between these measures and growth. Bringing equity market variables into our analysis, however, would limit its scope to those countries and years for which stock market data are available, and would reduce the number of observations by more than half. Since our aim is to examine the robustness of the most fundamental links between finance and long-run growth found in the early literature on the subject, we prefer a compact yet more complete treatment of the more traditional measures of financial sector development. 
where $Y_{i t}$ is the growth rate of real per capita GDP, $F_{i t}$ is a measure of financial sector development, and $\mathrm{X}_{\mathrm{it}}$ is a set of baseline explanatory variables that have been shown empirically to be robust determinants of growth. The $\mathrm{X}$ variables include the log of initial real per capita GDP, which should capture the tendency for growth rates to converge across countries and over time, and the log of the initial secondary school enrollment rate, which should reflect the extent of investment in human capital. We also run regressions that include the ratio of trade (i.e., imports plus exports) to GDP and the ratio of government final consumption to GDP as additional explanatory variables.

We estimate equation (1) with a panel of 5-year averages from 1960 to 2003. ${ }^{7}$ To reduce any simultaneity bias that would result from the influence of economic growth on the development of the financial sector, we follow the literature and use instrumental variables (two-stage least squares). Specifically, we attempt to extract the predetermined component of the financial variable by using its initial value (in each 5-year average) along with the initial values of government expenditure and trade as percentages of GDP as instruments in each regression equation.

\section{The decline in the finance-growth relationship}

Table 1 contains results from the baseline growth equations for each of the three measures of financial depth for the full data period, 1960-2003. The results are largely consistent with the consensus in the literature. The coefficients on the financial variables are positive and significant, although only at the 10 percent level in the specification with the ratio of private credit to GDP. However, the coefficients are smaller than those reported in King and Levine (1993), which suggests that there might be some heterogeneity in the sample over time that needs to be explored. The control variables government expenditure and trade as percentages of GDP - are significant and have the expected signs, but their presence or absence does not have much effect on the finance coefficients. There are some differences in other coefficients between the two

\footnotetext{
${ }^{7}$ There is thus a maximum of 9 panel observations for each country. The last panel observation includes data averaged over only four years.
} 
specifications. Only in the simpler specification is the coefficient on the log of initial real GDP negative (although not statistically significant), which would be consistent with the notion of beta convergence. The positive and significant coefficients on the log of the initial secondary school enrollment rate suggest that human capital investment matters for growth.

The differences in these results from earlier published work with the same data definitions call for explanation. Our results extend the data sets used in earlier work to 2003 while the data in King and Levine's paper ends in $1989 .{ }^{8}$ In Table 2 we present estimates of baseline equations for two time periods. The first period, 1960-89, coincides with the data used by King and Levine and others that established the consensus results that have become so important. The second period, which runs from 1990 to 2003, is shorter but each panel equation still includes about 200 observations.

The differences between the two time periods are dramatic. The effect of financial depth on growth, which is always significant in the first 30-year period, all but disappears in the next 15. Whereas all of the finance coefficients are significant at the 5 percent level in the early time period, only one is significant at the 10 percent level in the more recent data. The coefficients on the M3 ratio fall by two-thirds and the others by more. Interestingly, the standard errors of the estimates are about the same in both periods. That is, the precision of the estimates is unchanged; the effects are simply smaller and therefore not significantly different from zero. The other coefficients in the growth equations are relatively stable across time periods. At the same time, a Chow test for the equality of all the coefficients across time periods in Table 2 rejects the hypothesis of stability at the 1 percent level.

To examine further the differences over time in the effect of financial depth on growth, we estimated the baseline equation separately with the cross section of data from each 5-year period. That is, from 1960 to 2003 there are nine cross sections. Estimates from instrumental variables regressions with each of the three measures of financial depth

${ }^{8}$ In addition, later editions of the World Bank's World Development Indicators provide some estimates for observations in earlier years that were previously missing. 
are shown in Tables 3, 4 and $5 .{ }^{9}$

The coefficient on M3 as a percent of GDP is positive and significant for four successive time periods running from 1965 to 1984 but insignificant in the earlier and subsequent periods (Table 3). The same is true for the coefficients on M3 less M1 (Table 4) with the exception of one time period in the 1970s where the coefficient drops. In contrast, the coefficient on the private credit ratio is only significantly different from zero in one time period (Table 5). But the coefficient on private sector credit is clearly positive (averaging .025) from the late 1960s to the early 1990s and then falls to zero or below. The coefficient on the M3 ratio falls to zero from 1985 on and the coefficient on M3 less M1 falls to zero from 1990 on. Once again, Chow tests for the regressions in each table reject the hypothesis of coefficient stability across the 9 time periods at the 1 percent level.

These tables provide a clear story. The finance effect on growth is a disappearing phenomenon. In the next section we examine two hypotheses that might explain the result.

\section{Understanding the changes in the finance growth relationship}

In this section we relate the finance growth relationship to the two hypotheses stated in the introduction (section 1). We relate the finance effect to, first, the incidence of financial crises and, second, to country efforts at financial liberalization.

The disappearance of the finance effect on growth over time may be related to the incidence of financial crises since such episodes are often associated with too-rapid financial deepening. There is a thin line between financial deepening that comes from the expansion of financial intermediary activity and financial deepening that is the consequence of a credit boom. In the first instance increased intermediation is likely to be growth enhancing, while in the second instance credit standards deteriorate, nonperforming loans proliferate and a banking crisis ensues. The effect of financial deepening on growth may have disappeared since the 1990s because many recent experiences with deepening have fallen into the second category.

\footnotetext{
${ }^{9}$ The tables show the specification that includes the government expenditure and trade variables. The results without these variables are indistinguishable.
} 
We investigate this hypothesis by isolating episodes of financial crisis and examining the impact of financial deepening on growth in non-crisis episodes. We use the identification and dating prepared by Capri and Klingebiel (2003) for systematic systemic banking and financial crises around the world. Of the 84 countries in our sample, 45 have experienced at least one major crisis. We characterize a 5-year country observation as a crisis period if the country was in crisis at any time during the period.

Instrumental variable estimates of the baseline growth equations that allow the finance coefficient to vary when there is either a major or minor financial crisis are shown in Table 6. Each equation shows the finance variable for all observations and then the finance variable interacted with dummies for crisis episodes. The size of the coefficient on the finance variable indicates the impact of finance on growth in non-crisis observations. These effects are all positive and significant and larger than the corresponding coefficients in Table 1, which does not account for crisis episodes. The interaction with the major crisis dummy indicates the difference in the finance effect when a country is in crisis. In every case, the finance effect is significantly smaller at the 5 percent level when there is a financial crisis. In fact, the impact of financial deepening in these crisis periods is often near zero. The minor crisis episodes also have a negative impact on the finance coefficients but the change is usually small and insignificant.

Since excessive credit creation can lead to instability and crisis, and financial liberalization is usually associated with the rapid development of financial institutions, capital flows, and increases in liquid liabilities, the disappearance of the finance effect on growth over time could represent an application of the Lucas critique. The Washington consensus about the benefits of financial liberalization emerged in the 1980s. Policy makers busily touted the benefits of liberalization of financial markets and the growth of financial institutions. Governments around the world took heed of the message and there was rapid growth in average levels of financial depth. However, in many of these countries credit and deposit growth took place without the requisite development of lending expertise, mechanisms for monitoring, and supervisory and regulatory skills. So the relationships observed in the early data disappeared as efforts to liberalize financial markets became widespread. One interpretation could therefore be that changing views about liberalization led to policy initiatives that did not replicate the earlier successes. 
In order to explore the impact of liberalizations we use the dating of equity market liberalizations in Bekaert, Harvey and Lundblad (2005). They use a variety of data sources to date an important element of financial sector liberalization, the liberalization of access by foreigners to the domestic equity market. This classification scheme can be applied to virtually all of the countries in our sample, and it turns out that a large number of countries experienced liberalization, although most of the liberalization occurred within a rather short period of time in the late 1980s and the early 1990s. Thus, we can associate our 5-year average growth observations with the liberalization status of the country. We separate our observations into four groups indicating whether a country was always liberalized, never liberalized, the pre-liberalization periods of countries that liberalized, and the corresponding post liberalization observations.

Instrumental variable estimates of the base line growth equations that allow the finance coefficient to vary with the country's liberalization status are shown in Table 7. Each equation shows the finance variable for all observations and then the finance variable interacted with dummies for three of the liberalization groups (the always liberalized group is omitted). Thus, the coefficients on the interaction variables are differences in the finance effect from the effect for always-liberalized countries. None of the interaction coefficients is significantly different from zero and they are all quite small. There is some indication that the finance effect is larger in never liberalized countries and smaller in countries prior to liberalization.

This result does not indicate that the finance effect on growth has been altered by equity market liberalizations, and thus does not offer direct support for the hypothesized Lucas type effect. Of course, it might be difficult to identify the effect of liberalizations on the coefficient on financial deepening because the liberalization itself often promotes growth. Indeed, Bekaert, Harvey and Lundblad find that that equity market liberalizations increase growth rates by a full percentage point. It might also be hard to distinguish this change from the effect of time (since all the post liberalization observations are later on) although time period fixed effects are included in all the equations. ${ }^{10}$

${ }^{10}$ For example, an additional explanation might be that there are distinct characteristics of the two decades, the 70s and 80s, that made the financial ratios seem to cause growth at that time but not otherwise. Those decades are dominated by the oil shocks and 
The conclusion to be drawn from Tables 6 and 7 is clear. The decline in the finance coefficients over time is not an inexplicable time effect or the direct result of a Lucas critique eroding the value of financial deepening. The coefficients are smaller in recent years because of the increased incidence of financial and banking crises. Financial deepening promotes growth as long as it is not excessive. Once excessive growth of money and credit leads to a crisis in the banking system, the benefits of financial deepening disappear until the crisis is cleaned up.

\section{Additional evidence}

In this section we examine some additional sample composition effects that might affect the relationship between finance and growth. Specifically, we look at the variation of the finance effect with the level of initial financial depth in a country and with the level of per capita income in a country. In the first instance, we look to see whether financial deepening has a payoff in countries with undeveloped financial sectors as well as those with already developed financial sectors. In the second instance, we look to see whether financial deepening pays off in low income countries as well as in high income countries.

We explore these issues with a rolling regression techniques first applied to study of the finance-growth nexus by Rousseau and Wachtel (2002). In that paper we showed that the cross-sectional relationship between finance and growth vanished in high inflation environments.

To systematically examine the effects of sample composition, we present results from two rolling IV regressions with that use the simple baseline equation and the M3 ratio as the finance variable. ${ }^{11}$ Figure 1 shows the evolution of the finance coefficient for 20country rolling windows, with each panel using an alternative metric along the horizontal axis. In each panel the solid line gives the estimated coefficients and 5 percent confidence intervals are given by the dotted lines.

periods of high inflation in many countries. It could well be that greater financial depth is associated with growth because these countries are better able to withstand the large nominal shocks that characterize the period. This would in fact be a benefit of deeper financial institutions but would not imply that increases in financial depth cause growth. 
In panel (a) we order the countries by the average level of financial depth (after adjusting for global time effects) and roll them in as the ratio of M3 to GDP increases. The initial regression includes the 20 countries with the lowest levels of financial depth and rolls in additional countries and rolls out the initial countries one by one so that each coefficient is from an estimate with a constant 20-country window. Thus, the coefficients from the 20-country windows in panel (a) reflect the effects of finance on growth among countries with relatively similar financial sectors.

The results are striking; financial deepening matters when the M3 to GDP ratio is around the middle of the observed range (about 50\%). Among the financially less developed countries the coefficient is sometimes negative, is quite variable, and is imprecisely measured. Among the financially most developed countries the coefficient is about zero; although financial depth differs a lot among these countries it has no relationship to growth.

In panel (b), we turn to the relationship between the finance effect on growth and the level of per capital income. It shows results from rolling regressions with a 20-country window where countries are rolled in by increasing average per capita income (in 1995 U.S. dollars). ${ }^{12}$ For very low income countries (income below $\$ 3,000$ ), the effect of financial deepening is positive but not significant. The effect is imprecisely estimated because in many of these countries increased financial depth might be due to directed finance and poor lending standards. However, in the middle income range (from $\$ 3,000$ to $\$ 12,000)$, there seems to be clear evidence of a finance growth relationship. At these income levels, groups of countries that are relatively homogeneous by income have different growth experiences that are related to financial depth. The relationship disappears among higher income countries with the coefficients around zero. These results indicate that the finance growth nexus appears to be stronger in certain economic environments. Countries with moderately developed financial sectors or countries with

\footnotetext{
${ }^{11}$ The overall estimates for the entire sample are given in the first column of Table 1. ${ }^{12}$ We establish an income ordering of countries by regressing the initial values of per capita income in each 5-year period for all of the countries in our sample on a constant and dummy variables for the time periods. We then use the averages of the adjusted series for each country (i.e., the residuals with the constant term added back in).
} 
middle levels of per capita income have a stronger and significant impact of financial deepening on economic growth.

\section{Conclusion}

In this paper we examine the robustness of some now-classic findings on the crosscountry relationship between financial development and economic growth. The financegrowth relationship that was estimated with data from the 1960s to the 1980s simply disappears in the past fifteen years. One might conclude that the underlying relationship that is so widely used is simply unstable. Instead, we investigate some simple and related hypotheses that might explain the time effects.

First, we test whether the incidence of domestic banking and financial crises affects the impact of deepening. Here the evidence is very strong. Financial deepening has a strong impact on growth throughout the sample period as long as a country can avoid a financial crisis. In crisis episodes, which are more often than not due to excessive deepening, the benefits of financial deepening, not surprisingly, disappear.

Second, we test to see whether an affect analogous to the Lucas critique is at work. In the context of our problem, it would imply that financial deepening causes growth as long as the relationship is not exploited. That is, policy makers who try to take advantage of the benefits of financial deepening might do so without adequate precautions in place. We use international equity market opening as an indicator of liberalization and find that the effect of financial deepening does not weaken when liberalizations occur. Our evidence does not support a direct Lucas-type argument, though it does not preclude that the possibility that too-rapid liberalization contributes to a higher incidence of growthinhibiting financial crises.

All of this does not detract from the basic point that at one time countries with higher levels of financial development tended to have higher growth rates than those with lower levels of financial development. The question of how these countries acquired large financial sectors and how they may have served as engines of growth, however, remains imperfectly understood. Did finance emerge due to the presence of deeper institutional fundamentals that had a direct impact on growth as Acemoglu, Johnson, and Robinson (2001) suggest? Or is Joan Robinson (1952) correct that growth is the prime mover 
behind financial development? Our study, while by no means arguing that financial factors is no longer important for economic development, serves simply as a reminder that the link between finance and growth is more complex than the simple relationships suggest. It would appear that deepening needs to be accompanied by appropriate policies for financial sector reform and regulation. Thus, the systematic study of the financial development experiences of individual countries becomes all the more critical as the next step in furthering our understanding of the nexus.

\section{References}

Acemoglu, Daron, Simon Johnson, and James A. Robinson, "The Colonial Origins of Economic Development: An Empirical Investigation,” American Economic Review, 91 (2001), 1369-1401.

Arestis, Philip, Panicos O. Demetriades, and Kul B. Luintel, "Financial Development and Economic Growth: The Role of Stock Markets,” Journal of Money, Credit, and Banking, 33 (2001), 16-41.

Barro, Robert J., "Economic Growth in a Cross Section of Countries," Quarterly Journal of Economics, 106 (1991), 407-43.

Bekaert, Geert, Campbell R. Harvey and Christian Lundblad, “Does Financial Liberalization Spur Growth?” Journal of Financial Economics, 77 (2005), 3-55.

Caprio, Gerard and Daniela Klingebiel. "Episodes of Systemic and Borderline Financial Crises,” mimeo, World Bank, 2003.

Demetriades, Panicos O., and Khaled A. Hussein, "Does Financial Development Cause Economic Growth? Time Series Evidence from Sixteen Countries," Journal of Development Economics, 51 (1996), 387-411.

Goldsmith, Raymond W., Financial Structure and Development (New Haven, Yale University Press, 1969).

King, Robert G., and Ross Levine, "Finance and Growth: Schumpeter Might Be Right,” Quarterly Journal of Economics, 108 (1993), 717-37.

Levine, Ross, "Financial Development and Economic Growth: Views and Agenda," Journal of Economic Literature, 35 (1997), 688-726. 
Levine, Ross, “Finance and Growth: Theory and Evidence,” in Philipe Aghion and Steven N. Durlauf, eds., Handbook of Economic Growth, Volume 1A (Amsterdam: Elsevier North Holland, 2005), pp. 865-934.

Levine, Ross and Sara Zervos, “Stock Markets, Banks, and Economic Growth,” American Economic Review, 88 (1998), 537-58.

Loayza, Norman V. and Romain Ranciere, "Financial Development, Financial Fragility, and Growth,” Journal of Money, Credit, and Banking, (38) 2006, 1051-76.

Lucas, Robert E., Jr., “Econometric Policy Evaluation: A Critique,” CarnegieRochester Series on Public Policy, 1 (1975), 19-46.

Lucas, Robert E., Jr., “On the Mechanics of Economic Development,” Journal of Monetary Economics 22 (1988), 3-42.

Manning, Mark J., “Finance Causes Growth: Can We Be So Sure?” Contributions to Macroeconomics, 3 (2003), http://www.bepress.com/bejm/contributions/vol3/iss1/art12

McKinnon, Ronald I., Money and Capital in Economic Development (Washington, DC: The Brookings Institution, 1973).

McKinnon, Ronald I., The Order of Economic Liberalization (Baltimore and London: The Johns Hopkins University Press, 1991).

Rioja, Felix, and Neven Valev, "Does One Size Fit All? A Reexamination of the Finance and Growth Relationship,” Journal of Development Economics, 74 (2004), 42947.

Robinson, Joan, “The Generalization of the General Theory,” in The Rate of Interest and Other Essays (London: Macmillan, 1952).

Rousseau, Peter L., and Paul Wachtel, "Equity Markets and Growth: Cross-Country Evidence on Timing and Outcomes, 1980-1995,” Journal of Banking and Finance, 24 (2000), 1933-57.

Rousseau, Peter L., and Paul Wachtel, "Inflation Thresholds and the Finance-Growth Nexus,” Journal of International Money and Finance 21 (2002), 277-93.

Temple, Jonathan, “The new growth evidence,” Journal of Economic Literature, 37 (1999), 112-56.

Wachtel, Paul, “How Much Do We Really Know about Growth and Finance?” Federal Reserve Bank of Atlanta Economic Review 88 (2003), 33-47. 
Table 1

Baseline instrumental variables growth regressions, 1960-2003

Dependent variable: \% Growth of per capita real GDP

\begin{tabular}{|c|c|c|c|c|c|c|}
\hline & (1) & (2) & (3) & (4) & (5) & (6) \\
\hline $\begin{array}{l}\text { Log of initial real per } \\
\text { capita GDP (1995 US\$) }\end{array}$ & $\begin{array}{l}-0.143 \\
(0.102)\end{array}$ & $\begin{array}{c}0.005 \\
(0.107)\end{array}$ & $\begin{array}{l}-0.168 \\
(0.104)\end{array}$ & $\begin{array}{l}-0.034 \\
(0.109)\end{array}$ & $\begin{array}{l}-0.082 \\
(0.116)\end{array}$ & $\begin{array}{c}0.024 \\
(0.118)\end{array}$ \\
\hline $\begin{array}{l}\text { Log of secondary school } \\
\text { enrollment rate }\end{array}$ & $\begin{array}{l}0.750^{* *} \\
(0.178)\end{array}$ & $\begin{array}{l}0.681^{* *} \\
(0.177)\end{array}$ & $\begin{array}{l}0.757^{* *} \\
(0.178)\end{array}$ & $\begin{array}{l}0.705^{* *} \\
(0.177)\end{array}$ & $\begin{array}{l}0.878^{* *} \\
(0.176)\end{array}$ & $\begin{array}{l}0.812^{* *} \\
(0.174)\end{array}$ \\
\hline $\begin{array}{l}\text { Liquid liabilities (M3) } \\
\text { (\% of GDP) }\end{array}$ & $\begin{array}{l}0.017^{* *} \\
(0.004)\end{array}$ & $\begin{array}{l}0.017^{* *} \\
(0.004)\end{array}$ & & & & \\
\hline $\begin{array}{l}\text { M3 less M1 } \\
\text { (\% of GDP) }\end{array}$ & & & $\begin{array}{l}0.026^{* *} \\
(0.005)\end{array}$ & $\begin{array}{l}0.023^{* *} \\
(0.006)\end{array}$ & & \\
\hline $\begin{array}{l}\text { Private sector credit } \\
\text { (\% of GDP) }\end{array}$ & & & & & $\begin{array}{c}0.006 \\
(0.004)\end{array}$ & $\begin{array}{l}0.007^{*} \\
(0.004)\end{array}$ \\
\hline $\begin{array}{l}\text { Government expenditure } \\
\text { (\% of GDP) }\end{array}$ & & $\begin{array}{l}-0.084^{* *} \\
(0.022)\end{array}$ & & $\begin{array}{l}-0.083^{* *} \\
(0.023)\end{array}$ & & $\begin{array}{l}-0.077^{* *} \\
(0.021)\end{array}$ \\
\hline Trade (\% of GDP) & & $\begin{array}{l}0.009^{* *} \\
(0.004)\end{array}$ & & $\begin{array}{l}0.009^{* *} \\
(0.004)\end{array}$ & & $\begin{array}{l}0.012^{* *} \\
(0.003)\end{array}$ \\
\hline $\begin{array}{l}\mathrm{R}^{2} \\
\text { (No. observations) }\end{array}$ & $\begin{array}{l}.218 \\
(625)\end{array}$ & $\begin{array}{l}.251 \\
(620)\end{array}$ & $\begin{array}{l}.235 \\
(605)\end{array}$ & $\begin{array}{c}.262 \\
(601)\end{array}$ & $\begin{array}{c}.202 \\
(639)\end{array}$ & $\begin{array}{c}.241 \\
(633)\end{array}$ \\
\hline
\end{tabular}

The table reports coefficients from two-stage least squares regressions using 5-year averages of the data with standard errors in parentheses. * and ** denote statistical significance at the 10 percent and 5 percent levels respectively. Instruments include initial values of government expenditure, international trade, and the respective financial variable as a percentage of GDP, with initial values taken as the first observation of each 5-year period. The regressions also include a dummy variable for each time period. 
Table 2

Instrumental variables growth regressions for two subperiods

Dependent variable: \% Growth of per capita real GDP

1960-1989

$\begin{array}{lcc}\begin{array}{l}\text { Log of initial real per } \\ \text { capita GDP (1995 US\$) }\end{array} & \begin{array}{c}-0.054 \\ (0.123)\end{array} & \begin{array}{c}-0.037 \\ (0.126)\end{array} \\ \begin{array}{lll}\text { Log of secondary school } \\ \text { enrollment rate }\end{array} & \begin{array}{l}0.528^{* *} \\ (0.196)\end{array} & \begin{array}{l}0.508^{* *} \\ (0.193)\end{array} \\ \begin{array}{lll}\text { Liquid liabilities (M3) } \\ \text { (\% of GDP) }\end{array} & \begin{array}{l}0.026^{* *} \\ 0.028^{* *}\end{array} \\ & (0.006) & (0.006)\end{array}$

\section{M3 less M1 \\ (\% of GDP)}

Private sector credit

(\% of GDP)

Government expenditure

(\% of GDP)

Trade (\% of GDP)

$\mathrm{R}^{2}$

(No. observations)

$-0.137-0.064$

$\begin{array}{ll}-0.137 & -0.064 \\ 0.132) & (0.134)\end{array}$

$\begin{array}{ll}-0.118 & -0.056 \\ (0.146) & (0.146) \\ & \\ 0.716^{* *} & 0.676^{* *} \\ (0.194) & (0.191)\end{array}$

$\begin{array}{llll}0.616^{* *} & 0.601^{* *} & 0.716^{* *} & 0.676^{* *} \\ (0.196) & (0.104) & (0.194) & (0.191)\end{array}$

(0.006) (0.006)

$$
\begin{array}{ll}
0.033^{* *} & 0.034^{* *} \\
(0.007) & (0.007)
\end{array}
$$

$$
\begin{array}{ll}
0.021^{* *} & 0.024^{* *} \\
(0.007) & (0.007)
\end{array}
$$

\begin{tabular}{|c|c|c|c|c|c|}
\hline $\begin{array}{c}-0.402^{* *} \\
(0.194)\end{array}$ & $\begin{array}{c}-0.101 \\
(.217)\end{array}$ & $\begin{array}{c}-0.373^{* *} \\
(0.188)\end{array}$ & $\begin{array}{c}-0.101 \\
(.211)\end{array}$ & $\begin{array}{c}-0.261^{* *} \\
(0.207)\end{array}$ & $\begin{array}{r}-0.077 \\
(.217)\end{array}$ \\
\hline $\begin{array}{l}1.505^{* *} \\
(0.454)\end{array}$ & $\begin{array}{l}1.236^{* *} \\
(0.458)\end{array}$ & $\begin{array}{l}1.444^{* *} \\
(0.463)\end{array}$ & $\begin{array}{l}1.238^{* *} \\
(0.465)\end{array}$ & $\begin{array}{l}1.504^{* *} \\
(0.432)\end{array}$ & $\begin{array}{l}1.320^{* *} \\
(0.430)\end{array}$ \\
\hline \multirow[t]{5}{*}{$\begin{array}{c}0.008 \\
(0.006)\end{array}$} & $\begin{array}{c}0.003 \\
(0.007)\end{array}$ & & & & \\
\hline & & $\begin{array}{c}0.014^{*} \\
(0.008)\end{array}$ & $\begin{array}{c}0.007 \\
(0.009)\end{array}$ & & \\
\hline & & & & $\begin{array}{c}0.001 \\
(0.005)\end{array}$ & $\begin{array}{c}-0.007 \\
(0.006)\end{array}$ \\
\hline & $\begin{array}{c}-0.084^{* *} \\
(0.038)\end{array}$ & & $\begin{array}{c}-0.100^{* *} \\
(0.041)\end{array}$ & & $\begin{array}{c}-0.080^{* *} \\
(0.036)\end{array}$ \\
\hline & $\begin{array}{l}0.015^{* *} \\
(0.005)\end{array}$ & & $\begin{array}{l}0.014^{* *} \\
(0.005)\end{array}$ & & $\begin{array}{l}0.013^{* *} \\
(0.004)\end{array}$ \\
\hline $\begin{array}{c}.096 \\
(213)\end{array}$ & $\begin{array}{c}.148 \\
(208)\end{array}$ & $\begin{array}{c}.121 \\
(195)\end{array}$ & $\begin{array}{c}.168 \\
(191)\end{array}$ & $\begin{array}{c}.099 \\
(227)\end{array}$ & $\begin{array}{c}.158 \\
(221)\end{array}$ \\
\hline
\end{tabular}

$\begin{array}{ccc}-0.086^{* *} & -0.074^{* *} & -0.075^{* *} \\ (0.028) & (0.029) & (0.027) \\ & & \\ 0.005 & 0.006 & 0.012^{* *} \\ (0.005) & (0.005) & (0.005)\end{array}$

$\begin{array}{cccccc}.272 & .298 & .272 & .292 & .257 & .289 \\ (412) & (412) & (410) & (410) & (412) & (412)\end{array}$

1990-2003

The table reports coefficients from two-stage least squares regressions with standard errors in parentheses. * and ** denote statistical significance at the 10 percent and 5 percent levels respectively. Instruments include initial values of government expenditure, international trade, and the respective financial variable, with initial values taken as the first observation of each 5-year period. The regressions also include dummy variables for the 5-year time periods. 
Table 3

Instrumental variables growth regressions with M3 (\% of GDP), 5-year cross sections 1960-2003

Dependent variable: \% Growth of per capita real GDP

$\begin{array}{lllllllll}1960-64 & 1965-69 & 1970-74 & 1975-79 & 1980-84 & 1985-89 & 1990-94 & 1995-99 & 2000-03\end{array}$

\begin{tabular}{|c|c|c|c|c|c|c|c|c|c|}
\hline $\begin{array}{l}\text { Log of initial real per } \\
\text { capita GDP (1995 US\$) }\end{array}$ & $\begin{array}{c}0.470 \\
(0.360)\end{array}$ & $\begin{array}{l}-0.285 \\
(0.262)\end{array}$ & $\begin{array}{l}-0.085 \\
(0.303)\end{array}$ & $\begin{array}{l}-0.016 \\
(0.359)\end{array}$ & $\begin{array}{l}-0.131 \\
(0.336)\end{array}$ & $\begin{array}{c}0.330 \\
(0.286)\end{array}$ & $\begin{array}{l}-0.028 \\
(0.395)\end{array}$ & $\begin{array}{l}-0.024 \\
(.282)\end{array}$ & $\begin{array}{l}-0.253 \\
(.465)\end{array}$ \\
\hline $\begin{array}{l}\text { Log of secondary school } \\
\text { enrollment rate }\end{array}$ & $\begin{array}{c}0.348 \\
(0.448)\end{array}$ & $\begin{array}{l}0.783^{* *} \\
(0.330)\end{array}$ & $\begin{array}{c}0.629 \\
(0.433)\end{array}$ & $\begin{array}{l}-0.162 \\
(0.562)\end{array}$ & $\begin{array}{c}0.720 \\
(0.610)\end{array}$ & $\begin{array}{c}0.684 \\
(0.603)\end{array}$ & $\begin{array}{l}1.911^{* *} \\
(0.797)\end{array}$ & $\begin{array}{c}0.950 \\
(0.621)\end{array}$ & $\begin{array}{l}-0.313 \\
(1.046)\end{array}$ \\
\hline $\begin{array}{l}\text { Liquid liabilities (M3) } \\
\text { (\% of GDP) }\end{array}$ & $\begin{array}{l}-0.003 \\
(0.019)\end{array}$ & $\begin{array}{l}0.044^{* *} \\
(0.013)\end{array}$ & $\begin{array}{l}0.033^{* *} \\
(0.013)\end{array}$ & $\begin{array}{l}0.040^{* *} \\
(0.016)\end{array}$ & $\begin{array}{l}0.035^{* *} \\
(0.015)\end{array}$ & $\begin{array}{c}0.015 \\
(0.012)\end{array}$ & $\begin{array}{l}-0.001 \\
(0.014)\end{array}$ & $\begin{array}{l}-0.001 \\
(0.009)\end{array}$ & $\begin{array}{c}0.016 \\
(0.014)\end{array}$ \\
\hline $\begin{array}{l}\text { Government expenditure } \\
\text { (\% of GDP) }\end{array}$ & $\begin{array}{l}-0.033 \\
(0.113)\end{array}$ & $\begin{array}{c}0.014 \\
(0.066)\end{array}$ & $\begin{array}{l}-0.085 \\
(0.067)\end{array}$ & $\begin{array}{l}-0.128^{*} \\
(0.072)\end{array}$ & $\begin{array}{l}-0.022 \\
(0.062)\end{array}$ & $\begin{array}{l}-0.186^{* *} \\
(0.059)\end{array}$ & $\begin{array}{r}-0.177^{* *} \\
(0.072)\end{array}$ & $\begin{array}{l}-0.019 \\
(0.051)\end{array}$ & $\begin{array}{l}-0.037 \\
(0.073)\end{array}$ \\
\hline Trade (\% of GDP) & $\begin{array}{l}-0.006 \\
(0.014)\end{array}$ & $\begin{array}{l}-0.006 \\
(0.011)\end{array}$ & $\begin{array}{c}0.003 \\
(0.012)\end{array}$ & $\begin{array}{c}0.019 \\
(0.013)\end{array}$ & $\begin{array}{l}-0.007 \\
(0.012)\end{array}$ & $\begin{array}{l}0.020^{*} \\
(0.010)\end{array}$ & $\begin{array}{l}0.025^{* *} \\
(0.010)\end{array}$ & $\begin{array}{c}0.005 \\
(0.007)\end{array}$ & $\begin{array}{c}0.012 \\
(0.011)\end{array}$ \\
\hline $\begin{array}{l}\mathrm{R}^{2} \\
\text { (No. observations) }\end{array}$ & $\begin{array}{l}.133 \\
(52)\end{array}$ & $\begin{array}{l}.371 \\
(66)\end{array}$ & $\begin{array}{l}.218 \\
(67)\end{array}$ & $\begin{array}{l}.101 \\
(74)\end{array}$ & $\begin{array}{l}.115 \\
(78)\end{array}$ & $\begin{array}{l}.249 \\
(75)\end{array}$ & $\begin{array}{l}.268 \\
(81)\end{array}$ & $\begin{array}{l}.098 \\
(79)\end{array}$ & $\begin{array}{l}.103 \\
(48)\end{array}$ \\
\hline
\end{tabular}

The table reports coefficients from two-stage least squares regressions with standard errors in parentheses. . * and ** denote statistical significance at the 10 percent and 5 percent levels respectively. Instruments include initial values of the full set of regressors, with initial values taken as the first observation of each 5 -year period 
Table 4

Instrumental variables growth regressions with M3 less M1 (\% of GDP), 5-year cross sections 1960-2003

\begin{tabular}{|c|c|c|c|c|c|c|c|c|c|}
\hline & \multicolumn{9}{|c|}{ Dependent variable: \% Growth of per capita real GDP } \\
\hline & $1960-64$ & $1965-69$ & $1970-74$ & $1975-79$ & 1980-84 & 1985-89 & $1990-94$ & 1995-99 & 2000-03 \\
\hline $\begin{array}{l}\text { Log of initial real per } \\
\text { capita GDP (1995 US\$) }\end{array}$ & $\begin{array}{c}0.464 \\
(0.392)\end{array}$ & $\begin{array}{l}-0.350 \\
(0.256)\end{array}$ & $\begin{array}{l}-0.265 \\
(0.342)\end{array}$ & $\begin{array}{c}0.136 \\
(0.382)\end{array}$ & $\begin{array}{l}-0.247 \\
(0.355)\end{array}$ & $\begin{array}{c}0.083 \\
(0.284)\end{array}$ & $\begin{array}{l}-0.130 \\
(0.408)\end{array}$ & $\begin{array}{l}0.062 \\
(.306)\end{array}$ & $\begin{array}{l}-0.292 \\
(.376)\end{array}$ \\
\hline $\begin{array}{l}\text { Log of secondary school } \\
\text { enrollment rate }\end{array}$ & $\begin{array}{c}0.514 \\
(0.482)\end{array}$ & $\begin{array}{l}0.725^{* *} \\
(0.318)\end{array}$ & $\begin{array}{c}0.528 \\
(0.456)\end{array}$ & $\begin{array}{c}0.056 \\
(0.580)\end{array}$ & $\begin{array}{c}0.819 \\
(0.606)\end{array}$ & $\begin{array}{c}0.718 \\
(0.564)\end{array}$ & $\begin{array}{l}1.833^{* *} \\
(0.821)\end{array}$ & $\begin{array}{c}0.956 \\
(0.711)\end{array}$ & $\begin{array}{c}0.217 \\
(0.837)\end{array}$ \\
\hline $\begin{array}{l}\text { M3 less M1 } \\
\text { (\% of GDP) }\end{array}$ & $\begin{array}{c}0.003 \\
(0.026)\end{array}$ & $\begin{array}{l}0.066^{* *} \\
(0.014)\end{array}$ & $\begin{array}{l}0.044^{* *} \\
(0.020)\end{array}$ & $\begin{array}{l}0.012 \\
(0.019\end{array}$ & $\begin{array}{l}0.039^{* *} \\
(0.018)\end{array}$ & $\begin{array}{l}0.035^{* *} \\
(0.013)\end{array}$ & $\begin{array}{c}0.012 \\
(0.014)\end{array}$ & $\begin{array}{l}-0.007 \\
(0.015)\end{array}$ & $\begin{array}{c}0.001 \\
(0.016)\end{array}$ \\
\hline $\begin{array}{l}\text { Government expenditure } \\
\text { (\% of GDP) }\end{array}$ & $\begin{array}{l}-0.031 \\
(0.123)\end{array}$ & $\begin{array}{c}0.068 \\
(0.065)\end{array}$ & $\begin{array}{l}-0.060 \\
(0.069)\end{array}$ & $\begin{array}{l}0.129^{*} \\
(0.078)\end{array}$ & $\begin{array}{l}-0.011 \\
(0.065)\end{array}$ & $\begin{array}{c}-0.172^{* *} \\
(0.057)\end{array}$ & $\begin{array}{l}-0.174^{* *} \\
(0.077)\end{array}$ & $\begin{array}{l}-0.035 \\
(0.057)\end{array}$ & $\begin{array}{l}-0.033 \\
(0.069)\end{array}$ \\
\hline Trade (\% of GDP) & $\begin{array}{c}-0.002 \\
(0.015)\end{array}$ & $\begin{array}{l}-0.011 \\
(0.011)\end{array}$ & $\begin{array}{c}0.006 \\
(0.012)\end{array}$ & $\begin{array}{l}0.027^{* *} \\
(0.013)\end{array}$ & $\begin{array}{c}-0.006 \\
(0.013)\end{array}$ & $\begin{array}{c}0.015 \\
(0.010)\end{array}$ & $\begin{array}{l}0.023^{* *} \\
(0.010)\end{array}$ & $\begin{array}{c}0.009 \\
(0.008)\end{array}$ & $\begin{array}{c}0.013 \\
(0.009)\end{array}$ \\
\hline $\begin{array}{l}\mathrm{R}^{2} \\
\text { (No. observations) }\end{array}$ & $\begin{array}{l}.181 \\
(55)\end{array}$ & $\begin{array}{l}.441 \\
(64)\end{array}$ & $\begin{array}{l}.158 \\
(68)\end{array}$ & $\begin{array}{l}.134 \\
(73)\end{array}$ & $\begin{array}{l}.119 \\
(77)\end{array}$ & $\begin{array}{l}.297 \\
(73)\end{array}$ & $\begin{array}{l}.279 \\
(76)\end{array}$ & $\begin{array}{l}.109 \\
(72)\end{array}$ & $\begin{array}{l}.099 \\
(43)\end{array}$ \\
\hline
\end{tabular}

The table reports coefficients from two-stage least squares regressions with standard errors in parentheses. * and ** denote statistical significance at the 10 percent and 5 percent levels respectively. Instruments include initial values of the full set of regressors, with initial values taken as the first observation of each 5-year period. 
Table 5

Instrumental variables growth regressions with private sector credit (\% of GDP), 5-year cross sections 1960-2003

Dependent variable: \% Growth of per capita real GDP

$1960-64 \quad 1965-69 \quad 1970-74 \quad 1975-79 \quad 1980-84 \quad 1985-89 \quad 1990-94 \quad 1995-99 \quad 2000-03$

\begin{tabular}{|c|c|c|c|c|c|c|c|c|c|}
\hline $\begin{array}{l}\text { Log of initial real per } \\
\text { capita GDP (1995 US\$) }\end{array}$ & $\begin{array}{c}0.561 \\
(0.388)\end{array}$ & $\begin{array}{l}-0.266 \\
(0.333)\end{array}$ & $\begin{array}{l}-0.107 \\
(0.354)\end{array}$ & $\begin{array}{c}0.049 \\
(0.409)\end{array}$ & $\begin{array}{l}-0.109 \\
(0.371)\end{array}$ & $\begin{array}{l}-0.128 \\
(0.334)\end{array}$ & $\begin{array}{l}-0.054 \\
(0.418)\end{array}$ & $\begin{array}{l}0.173 \\
(.286)\end{array}$ & $\begin{array}{l}-0.429 \\
(.443)\end{array}$ \\
\hline $\begin{array}{l}\text { Log of secondary school } \\
\text { enrollment rate }\end{array}$ & $\begin{array}{c}0.325 \\
(0.428)\end{array}$ & $\begin{array}{l}0.899^{* *} \\
(0.357)\end{array}$ & $\begin{array}{c}0.713 \\
(0.440)\end{array}$ & $\begin{array}{c}0.078 \\
(0.566)\end{array}$ & $\begin{array}{c}0.940 \\
(0.603)\end{array}$ & $\begin{array}{c}0.838 \\
(0.565)\end{array}$ & $\begin{array}{l}2.018^{* *} \\
(0.761)\end{array}$ & $\begin{array}{c}0.903 \\
(0.611)\end{array}$ & $\begin{array}{c}0.041 \\
(0.924)\end{array}$ \\
\hline $\begin{array}{l}\text { Private sector credit } \\
\text { (\% of GDP) }\end{array}$ & $\begin{array}{c}0.004 \\
(0.022)\end{array}$ & $\begin{array}{c}0.029 \\
(0.019)\end{array}$ & $\begin{array}{c}0.026 \\
(0.018)\end{array}$ & $\begin{array}{l}0.020 \\
(0.020)\end{array}$ & $\begin{array}{l}0.014 \\
(0.017)\end{array}$ & $\begin{array}{l}0.037^{* *} \\
(0.014)\end{array}$ & $\begin{array}{l}-0.002 \\
(0.012)\end{array}$ & $\begin{array}{l}-0.005 \\
(0.007)\end{array}$ & $\begin{array}{c}0.014 \\
(0.010)\end{array}$ \\
\hline $\begin{array}{l}\text { Government expenditure } \\
\text { (\% of GDP) }\end{array}$ & $\begin{array}{l}-0.033 \\
(0.098)\end{array}$ & $\begin{array}{c}0.042 \\
(0.070)\end{array}$ & $\begin{array}{l}-0.059 \\
(0.068)\end{array}$ & $\begin{array}{l}-0.121 \\
(0.074)\end{array}$ & $\begin{array}{c}-0.018 \\
(0.062)\end{array}$ & $\begin{array}{c}-0.173^{* *} \\
(0.057)\end{array}$ & $\begin{array}{r}-0.163^{* *} \\
(0.070)\end{array}$ & $\begin{array}{c}-0.039 \\
(0.051)\end{array}$ & $\begin{array}{l}-0.025 \\
(0.064)\end{array}$ \\
\hline Trade (\% of GDP) & $\begin{array}{c}-0.009 \\
(0.012)\end{array}$ & $\begin{array}{c}0.007 \\
(0.012)\end{array}$ & $\begin{array}{c}0.010 \\
(0.012)\end{array}$ & $\begin{array}{l}0.029^{* *} \\
(0.013)\end{array}$ & $\begin{array}{c}0.001 \\
(0.012)\end{array}$ & $\begin{array}{l}0.025^{* *} \\
(0.010)\end{array}$ & $\begin{array}{l}0.021^{* *} \\
(0.008)\end{array}$ & $\begin{array}{l}0.010^{*} \\
(0.006)\end{array}$ & $\begin{array}{c}0.011 \\
(0.007)\end{array}$ \\
\hline $\begin{array}{l}\mathrm{R}^{2} \\
\text { (No. observations) }\end{array}$ & $\begin{array}{l}.217 \\
(52)\end{array}$ & $\begin{array}{l}.266 \\
(66)\end{array}$ & $\begin{array}{l}.189 \\
(66)\end{array}$ & $\begin{array}{l}.143 \\
(74)\end{array}$ & $\begin{array}{l}.099 \\
(79)\end{array}$ & $\begin{array}{l}.309 \\
(75)\end{array}$ & $\begin{array}{l}.251 \\
(82)\end{array}$ & $\begin{array}{l}.151 \\
(83)\end{array}$ & $\begin{array}{l}.107 \\
(56)\end{array}$ \\
\hline
\end{tabular}

The table reports coefficients from two-stage least squares regressions with standard errors in parentheses. $*$ and $* *$ denote statistical significance at the 10 percent and 5 percent levels respectively. Instruments include initial values of the full set of regressors, with initial values taken as the first observation of each 5-year period. 
Table 6

Instrumental variables growth regressions by crisis status, 1960-2003

\begin{tabular}{|c|c|c|c|c|c|c|}
\hline \multirow{3}{*}{$\begin{array}{l}\text { Financial Variable: } \\
\text { Log of initial real per } \\
\text { capita GDP (1995 US\$) }\end{array}$} & \multicolumn{6}{|c|}{ Dependent variable: \% Growth of per capita real GDP } \\
\hline & \multicolumn{2}{|c|}{ M3 (\% GDP) } & \multicolumn{2}{|c|}{ M3-M1 (\% GDP) } & \multicolumn{2}{|c|}{ Credit (\% GDP) } \\
\hline & $\begin{array}{l}-0.150 \\
(0.102)\end{array}$ & $\begin{array}{l}-0.005 \\
(0.106)\end{array}$ & $\begin{array}{l}-0.183^{*} \\
(0.104)\end{array}$ & $\begin{array}{l}-0.057 \\
(0.109)\end{array}$ & $\begin{array}{l}-0.132 \\
(0.117)\end{array}$ & $\begin{array}{l}-0.028 \\
(0.119)\end{array}$ \\
\hline $\begin{array}{l}\text { Log of secondary school } \\
\text { enrollment rate }\end{array}$ & $\begin{array}{l}0.722^{* *} \\
(0.177)\end{array}$ & $\begin{array}{l}0.654^{* *} \\
(0.176)\end{array}$ & $\begin{array}{l}0.739^{* *} \\
(0.177)\end{array}$ & $\begin{array}{l}0.695^{* *} \\
(0.176)\end{array}$ & $\begin{array}{l}0.876^{* *} \\
(0.175)\end{array}$ & $\begin{array}{l}0.814^{* *} \\
(0.173)\end{array}$ \\
\hline Finance & $\begin{array}{l}0.021^{* *} \\
(0.004)\end{array}$ & $\begin{array}{l}0.022^{* *} \\
(0.005)\end{array}$ & $\begin{array}{l}0.032^{* *} \\
(0.006)\end{array}$ & $\begin{array}{l}0.030^{* *} \\
(0.006)\end{array}$ & $\begin{array}{l}0.012^{* *} \\
(0.005)\end{array}$ & $\begin{array}{l}0.013^{* *} \\
(0.005)\end{array}$ \\
\hline $\begin{array}{l}\text { Finance x major } \\
\text { financial crisis }\end{array}$ & $\begin{array}{l}-0.016^{* *} \\
(0.005)\end{array}$ & $\begin{array}{l}-0.017^{* *} \\
(0.005)\end{array}$ & $\begin{array}{l}-0.024^{* *} \\
(0.008)\end{array}$ & $\begin{array}{l}-0.024^{* *} \\
(0.008)\end{array}$ & $\begin{array}{l}-0.014^{* *} \\
(0.005)\end{array}$ & $\begin{array}{l}-0.015^{* *} \\
(0.005)\end{array}$ \\
\hline $\begin{array}{l}\text { Finance } x \text { minor } \\
\text { financial crisis }\end{array}$ & $\begin{array}{l}-0.007 \\
(0.007)\end{array}$ & $\begin{array}{l}-0.005 \\
(0.007)\end{array}$ & $\begin{array}{l}-0.013 \\
(0.010)\end{array}$ & $\begin{array}{l}-0.009 \\
(0.010)\end{array}$ & $\begin{array}{l}-0.010^{*} \\
(0.006)\end{array}$ & $\begin{array}{l}-0.007 \\
(0.006)\end{array}$ \\
\hline $\begin{array}{l}\text { Government expenditure } \\
\text { (\% of GDP) }\end{array}$ & & $\begin{array}{l}-0.087^{* *} \\
(0.022)\end{array}$ & & $\begin{array}{l}-0.082^{* *} \\
(0.023)\end{array}$ & & $\begin{array}{l}-0.078^{* *} \\
(0.021)\end{array}$ \\
\hline Trade (\% of GDP) & & $\begin{array}{l}0.008^{* *} \\
(0.004)\end{array}$ & & $\begin{array}{l}0.008^{* *} \\
(0.004)\end{array}$ & & $\begin{array}{l}0.011^{* *} \\
(0.003)\end{array}$ \\
\hline $\begin{array}{l}\mathrm{R}^{2} \\
\text { (No. observations) }\end{array}$ & $\begin{array}{c}.230 \\
(625)\end{array}$ & $\begin{array}{c}.262 \\
(620)\end{array}$ & $\begin{array}{c}.247 \\
(606)\end{array}$ & $\begin{array}{c}.272 \\
(602)\end{array}$ & $\begin{array}{c}.214 \\
(639)\end{array}$ & $\begin{array}{c}.252 \\
(633)\end{array}$ \\
\hline
\end{tabular}

The table reports coefficients from two-stage least squares regressions using 5-year averages of the data with standard errors in parentheses. * and ** denote statistical significance at the 10 percent and 5 percent levels respectively. Instruments include initial values of government expenditure, international trade, and the respective interacted financial variables as percentages of GDP, with initial values taken as the first observation of each 5-year period. The regressions also include a dummy variable for each time period. 
Table 7

Instrumental variables growth regressions by liberalization status, 1960-2003

\begin{tabular}{|c|c|c|c|c|c|c|}
\hline \multirow{3}{*}{$\begin{array}{l}\text { Financial Variable: } \\
\text { Log of initial real per } \\
\text { capita GDP (1995 US\$) }\end{array}$} & \multicolumn{6}{|c|}{ Dependent variable: \% Growth of per capita real GDP } \\
\hline & \multicolumn{2}{|c|}{ M3 (\% GDP) } & \multicolumn{2}{|c|}{ M3-M1 (\% GDP) } & \multicolumn{2}{|c|}{ Credit (\% GDP) } \\
\hline & $\begin{array}{l}-0.138 \\
(0.104)\end{array}$ & $\begin{array}{c}0.012 \\
(0.108)\end{array}$ & $\begin{array}{l}-0.161 \\
(0.110)\end{array}$ & $\begin{array}{l}-0.026 \\
(0.111)\end{array}$ & $\begin{array}{l}-0.087 \\
(0.117)\end{array}$ & $\begin{array}{c}0.024 \\
(0.120)\end{array}$ \\
\hline $\begin{array}{l}\text { Log of secondary school } \\
\text { enrollment rate }\end{array}$ & $\begin{array}{l}0.740^{* *} \\
(0.181)\end{array}$ & $\begin{array}{l}0.669^{* *} \\
(0.178)\end{array}$ & $\begin{array}{l}0.755^{* *} \\
(0.180)\end{array}$ & $\begin{array}{l}0.709^{* *} \\
(0.178)\end{array}$ & $\begin{array}{l}0.873^{* *} \\
(0.176)\end{array}$ & $\begin{array}{l}0.811^{* *} \\
(0.174)\end{array}$ \\
\hline Finance & $\begin{array}{l}0.017^{* *} \\
(0.004)\end{array}$ & $\begin{array}{l}0.016^{* *} \\
(0.005)\end{array}$ & $\begin{array}{l}0.025^{* *} \\
(0.006)\end{array}$ & $\begin{array}{l}0.022^{* *} \\
(0.006)\end{array}$ & $\begin{array}{l}0.007^{*} \\
(0.004)\end{array}$ & $\begin{array}{l}0.007^{*} \\
(0.004)\end{array}$ \\
\hline $\begin{array}{l}\text { Finance } x \\
\text { never liberalized }\end{array}$ & $\begin{array}{c}0.002 \\
(0.005)\end{array}$ & $\begin{array}{c}0.004 \\
(0.005)\end{array}$ & $\begin{array}{c}0.004 \\
(0.007)\end{array}$ & $\begin{array}{c}0.007 \\
(0.007)\end{array}$ & $\begin{array}{l}-0.001 \\
(0.004)\end{array}$ & $\begin{array}{c}0.001 \\
(0.004)\end{array}$ \\
\hline $\begin{array}{l}\text { Finance } \mathrm{x} \\
\text { pre-liberalization }\end{array}$ & $\begin{array}{l}-0.001 \\
(0.006)\end{array}$ & $\begin{array}{l}-0.002 \\
(0.006)\end{array}$ & $\begin{array}{l}-0.005 \\
(0.009)\end{array}$ & $\begin{array}{l}-0.007 \\
(0.009)\end{array}$ & $\begin{array}{l}-0.005 \\
(0.006)\end{array}$ & $\begin{array}{l}-0.006 \\
(0.006)\end{array}$ \\
\hline $\begin{array}{l}\text { Finance } \mathrm{x} \\
\text { post liberalization }\end{array}$ & $\begin{array}{c}0.002 \\
(0.006)\end{array}$ & $\begin{array}{c}0.001 \\
(0.006)\end{array}$ & $\begin{array}{l}0.003 \\
(0.009)\end{array}$ & $\begin{array}{c}0.000 \\
(0.009)\end{array}$ & $\begin{array}{c}0.007 \\
(0.006)\end{array}$ & $\begin{array}{l}0.003 \\
(0.007)\end{array}$ \\
\hline $\begin{array}{l}\text { Government expenditure } \\
\text { (\% of GDP) }\end{array}$ & & $\begin{array}{l}-0.087^{* *} \\
(0.022)\end{array}$ & & $\begin{array}{l}-0.088^{* *} \\
(0.023)\end{array}$ & & $\begin{array}{l}-0.076^{* *} \\
(0.022)\end{array}$ \\
\hline Trade (\% of GDP) & & $\begin{array}{l}0.009^{* *} \\
(0.004)\end{array}$ & & $\begin{array}{l}0.010^{* *} \\
(0.004)\end{array}$ & & $\begin{array}{l}0.011^{* *} \\
(0.003)\end{array}$ \\
\hline $\begin{array}{l}\text { Exclude liberalization } \\
\text { variables (p-value) }\end{array}$ & 0.934 & 0.344 & 0.797 & 0.536 & 0.437 & 0.692 \\
\hline $\begin{array}{l}\mathrm{R}^{2} \\
\text { (No. observations) }\end{array}$ & $\begin{array}{l}.219 \\
(625)\end{array}$ & $\begin{array}{l}.253 \\
(620)\end{array}$ & $\begin{array}{l}.243 \\
(606)\end{array}$ & $\begin{array}{l}.265 \\
(602)\end{array}$ & $\begin{array}{l}.205 \\
(639)\end{array}$ & $\begin{array}{c}.242 \\
(633)\end{array}$ \\
\hline
\end{tabular}

The table reports coefficients from two-stage least squares regressions using 5-year averages of the data with standard errors in parentheses. * and ** denote statistical significance at the 10 percent and 5 percent levels respectively. Instruments include initial values of government expenditure, international trade, and the respective interacted financial variables as percentages of GDP, with initial values taken as the first observation of each 5-year period. The regressions also include a dummy variable for each time period. 

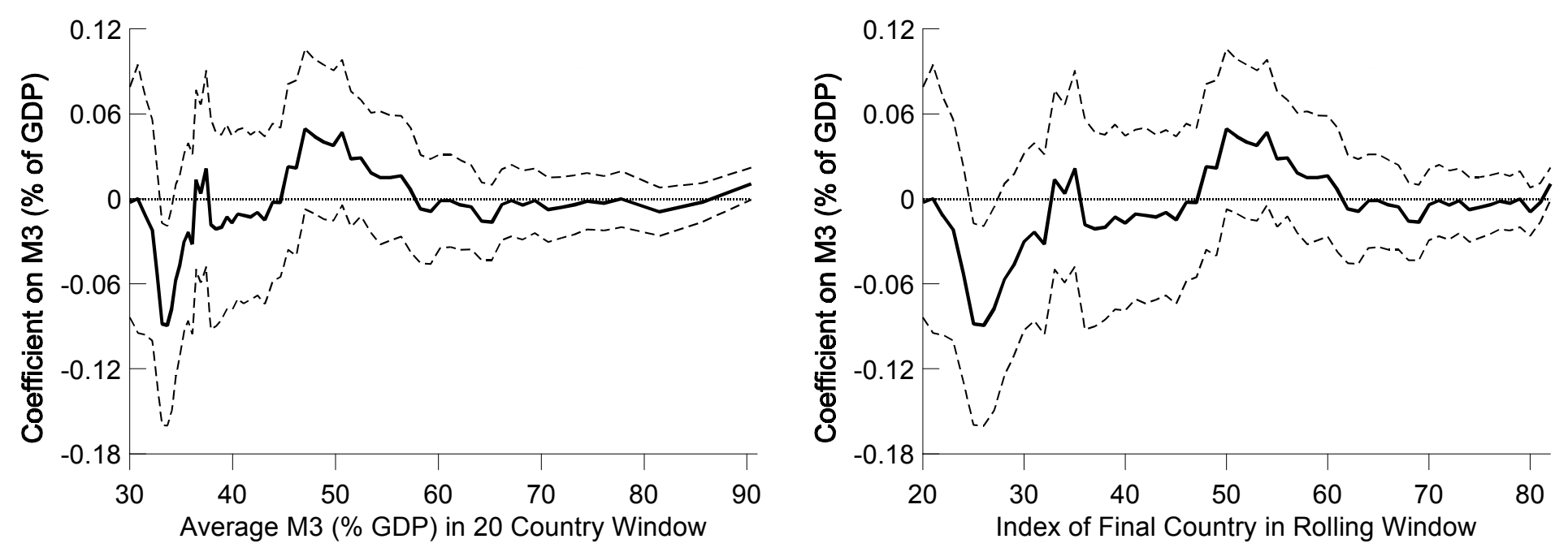

(a) 20-country rolling window ordered by increasing M3 (\% of GDP)
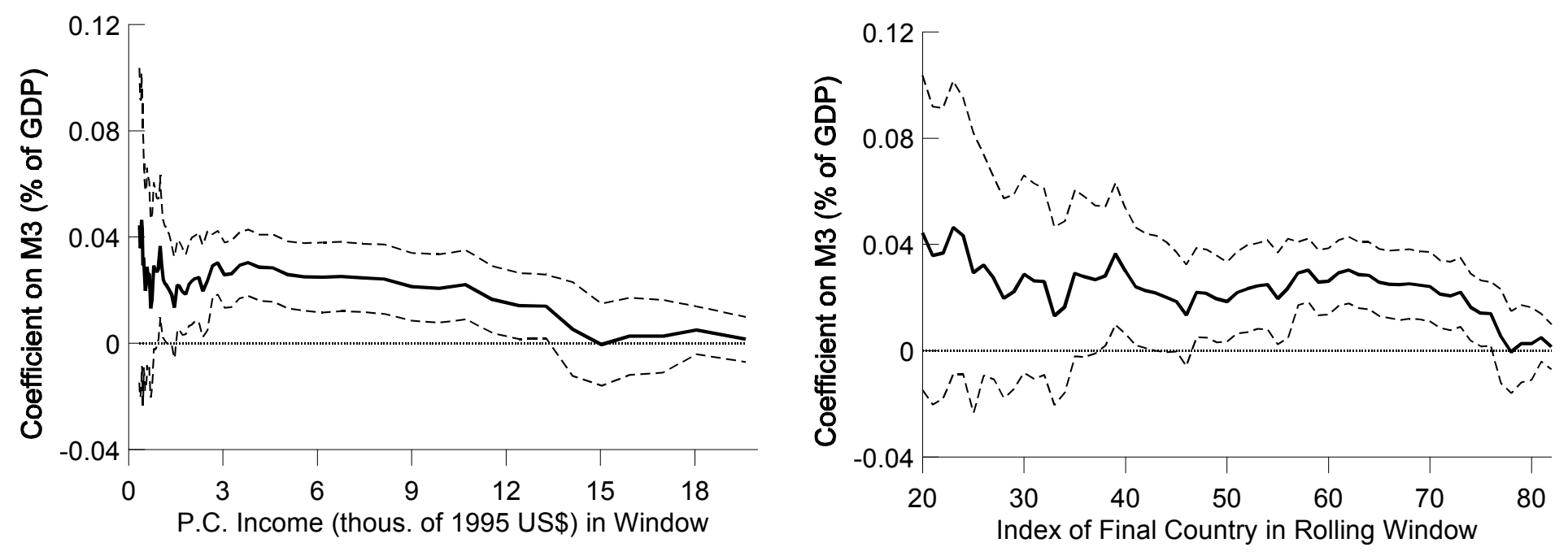

(b) 20-country rolling window order by increasing per capita income (thousands of 1995 U.S.\$)

Fig. 1. Evolution of coefficients on M3 (\% GDP) in rolling window cross country regressions 1960-2003. 